plete certainty in the theory of burning, or that no unsolved problems will remain in this field of research. Here, as in the theory of chain reactions, a solid basis has been laid, the physical meaning of the processes has been clarified, and the method of approach established. Nevertheless, each individual reaction requires a special study, its specific character being different.

In this way we have worked step by step during the last twenty-five years in developing chemical kineties in close contact with the English and American men of science who have frequently attended our conferences or sent us their papers.

Now our work has been interrupted. Many young workers of this Institute voluntarily joined the army during the first days of the War ; one of my closest associates and followers, P. Sadovnikov, whose name is known among scientific circles of Great Britain, has been killed. But the majority of our collaborators are still in the laboratories of the Institute, where work has been greatly intensified.

\section{HYDRO-ELECTRIC DEVELOPMENT IN SCOTLAND}

$\mathrm{O}^{\mathrm{N}}$ October 27, 1941, the Lord Advocate for Scotland, then the Right Hon. Lord Cooper, was appointed chairman of a committee of five to inquire into a report on hydro-electric development in Scotland. The report now issued* is dated August 24, 1942-so the Committee wasted no time. The Committee recognizes that hydro-electric planning is a matter for many years ahead--though it may not be out of place to remark that the national grid in Great Britain is an established success for war as well as peace conditions.

In the historical survey, the record of the last twenty years, with its six successive abortive promotions, comes boldly and badly into the picture. All major issues of policy, both national and local, have tended to become completely submerged in the conflict of contending national interests. But even governments do not escape if their policy is that they will neither develop the resources themselves nor allow anyone else to do so.

Excluding all burghal areas, the overall density of population on the mainland of the Northern Area is less than 20 per square mile. Northern Scotland is the only part of Great Britain not covered by the Grid scheme. The Committee finds that for such an area the policy embodied in the 1926 Act (which led to the formation of the Central Electricity Board) is essentially inappropriate and inapplicable. The progress of the Grampian Company, the control of which was obtained by the Scottish Power Company, in 1927, is traced. By supplying 106 million units per annum to the Central Electricity Board, the Grampian Company has an assured market to enable it to embark on a general supply in an extensive and sparsely populated territory. In 1940, the units sold, other than to the Central Electricity Board, totalled 63 million at an average of $1.55 d$. per unit. Here, then, is indicated a practical way for development. The Committee considers these results to justify the decision of the Electricity Commissioners and Central

- Scottish Office. Report of the Committee on Hydro-Electric Development in Scotland. (Cmd. 6406.) Pp. 38. (London and EdinDevelopment in Scotland. (Cmd. 6406.) Pp. 38.
burgh : H.M. Stationery office, 1942.) $9 d$. net.
Electricity Board in 1931 to leave the development of this area to the Grampian Company.

Commenting on the criticisms against the Grampian Company, the report shows a sympathetic appreciation. Even so, doubts may still exist. On one occasion, when the present writer was visiting the Loch Rannoch and Tummelbridge Works, it struck him as strange to see two joiners making a coffin by candlelight in a house in the village of Kinloch Rannoch.

In the existing state, it is stressed that it will be essential at the earliest possible date to provide a substantial new source of power in the extreme north of the Grampian territory, to meet normal expansion. To construct a large steam station in a district so remote from coal and so rich in water-power would involve a major error of misplanning. It is not agreed that the cancellation of the bulk supply to the Central Electricity Board would solve the problem, both because of the effect of the loss of the contract, and the fact that Loch Rannoch and Tummelbridge Works have been designed for a 50 per cent load factor and not for supplying a general demand.

In the study of comparative costs of steam and hydro-electric generation, attention is directed to the rising price of coal in recent years, and in the fall in the basic rate of interest-the main components in the cost of electricity generated from steam and water respectively. On the financial side, the Committee considers its recommendations preferable to the provision of an equivalent capacity of new steam plant. Any likely improvement in water or steampower technique is unlikely to influence the position. Provisional estimates disclose some seventy favourable schemes in the Northern Area capable of yielding not less than 4,000 million units per annum, or $450,000 \mathrm{~kW}$. continuous.

Of the opposing theories for revitalizing the Highlands, the Committee regards the introduction of modern industries in which an abundant supply of cheap electricity is indispensable as the only means of securing a prosperous population in the area. These industries are electro-chemical and electrometallurgical: calcium carbide and cyanamide; reduction or refining processes for aluminium, copper, zinc, vanadium and cadmium; the ferro-alloys. The defeat of the Caledonian Power Bill is regarded as a tragic mistake, not only for Scotland but also for Great Britain. Assuming that these industries on a substantial scale are essential to Great Britain, northern Scotland offers the only solution. By suitable planning, natural beauty can be preserved. The Committee challenges the critics to offer any other scheme to arrest the growing decay in the Highlands.

From independent computations, it is found that the ultimate local demand for general supply represents about 8 per cent of the ultimate power capable of development; consequently the position for the local population would be adequately safeguarded. In the long-term plan of development, the national grid forms the indispensable background as a market for surplus power.

The Committee's recommendations include the creation of a non-profit-earning, public-service corporation to work in close partnership with the Central Electricity Board. This new corporation would be responsible for the further development of electricity generation, transmission and distribution in the Northern Area. The corporation should attract to the Highlands a share of the industries demanding abundant and cheap power, develop such further 
power as may be required, and develop on an experimental basis isolated schemes in isolated districts. Local requirements should be given priority.

The Committee also considered the safeguarding of fishery interests, the need for compulsory powers, the present inequitable valuation and'rating of hydroelectric undertakings, and the preservation of the amenities.

From the foregoing digest of the report, it will be seen that the Committee has not only considered all relevant matters, but has also taken into account the views of opposing interests. A careful examination of the report leads to the conclusion that this is the first complete study that has been made of this matter, and that the general conclusions reached are the only sound ones possible.

\section{S. PARKer SMITH.}

\section{OBITUARIES}

\section{Dr. C. Tate Regan, F.R.S.}

Charles Tate Regan, formerly director of the British Museum (Natural History), who died on January 12, was born at Sherborne in February 1878 and was educated at Derby School and Queens' College, Cambridge. The choice of Derby was probably influenced by the fact that his parents were professional musicians, for the head-master at that time was J. R. Sterndale-Bennett, a son of the composer, and music took a serious place in the life of the School. The appreciation of great music thus inherited and cultivated gave Tate Regan great pleasure in later years. It was L. J. Fuller, the science master at Derby, who first suggested a career at the Natural History Museum to the boy, among whose interests natural history was already prominent, and Tate Regan stayed a fourth year at Cambridge to wait for a vacancy to occur at South Kensington. At Cambridge he studied under Sedgwick, and he worked and played with equal zest. He played both Association and Rugby football, and was a good sprinter, hurdler and jumper. At this time he was uncertain whether to specialize in plants or animals, but of one thing he was sure, that his interest would be in the structure of living organisms, and its bearing on their relationships and evolution.

In 1901 Regan joined the staff of the British Museum (Natural History). Günther, who was then keeper of zoology, advised him to specialize in fishes, and he joined G. A. Boulenger on this group, starting, at Günther's suggestion, with a revision of the family Stromateidr, which was the subject of his first paper (1902). Boulenger had just received the proofs of the "Cambridge Natural History" volume on fishes, and asked his young colleague to look through them. Regan suggested that the Gadoidea were wrongly placed and Boulenger challenged him to prove it, finally accepting Regan's arguments (published in 1903) and altering the book accordingly. Regan would tell this story in later years, wondering at his own temerity.

From this time on, every year saw a long list of titles under Regan's name in the Zoological Record, and one is left amazed at the mental energy that allowed him to work on so many lines at once. His most important contribution to.ichthyology was the series of papers on the major classification of living fishes, beginning with the "Classification of the Selachian Fishes" (1906) and continuing with the Teleostean orders and sub-orders, which were treated severally in some score of papers appearing in the Annals and Magazine of Natural History, mainly during the years 1911-13. This work was based on the study of a big collection of dried skeletons and on spirit specimens, and was written in a form and style so concise as to give little idea of the amount of research behind it. It is summarized in articles on selachians and fishes in the fourteenth edition of the "Encyclopædia Britannica", and presents a classification which is accepted as a basis by serious ichthyological workers all over the world.

In 1911 there appeared a work of a very different type, "The Freshwater Fishes of the British Isles". This is perhaps the most fascinating of Regan's works, combining as it does the results of intensive studies in the museum with knowledge gained in delightful days spent angling in the rivers and streams near his home in Dorset, and in visits to the English and Scottish lakes that harbour the relict char. At once authoritative and readable, this is a model book of popular natural history.

It fell to Regan's lot to write the section on fishes in the "Biologia Centrali-Americana" (1906-8) and to report on the fishes of the Antarctic expeditions of the Scotia (1913) and Terra Nova (1914, 1916). From these results syntheses were made which increased considerably our knowledge of the laws governing the geographical distribution of fishes. His conclusions on this subject, too, are gathered together in an "Encyclopædia Britannica" article. Regan's systematic revisions of families are many, and in every case have that masterly quality which has put subsequent work upon a sound basis, and has been a powerful influence in keeping the standard of systematic ichthyology high.

I first met Dr. Regan in 1921, when as a student I visited the Museum to learn something about the classification of fishes, and received unstinted help. Regan had then just become keeper of zoology. When, in 1927, he was appointed director, he found that administrative duties left him little time for scientific work. He was able, as always, to do a great deal in the evenings, but he needed a collaborator who could deal with the practical work on the collections all day, allowing him to follow it in what time he could spare, and in the following year I was appointed as his scientific assistant. $\mathrm{He}$ had already, in 1925, dealt with the deep-sea anglerfishes of the first Dana expedition, and had described for the first time the dwarfed and parasitic males of this group. He was now about to tackle the Dana Stomiatoid fishes, and had also large collections of African Cichlidæ to work out. I soon understood that I was highly privileged to work upon such material under the guidance of such a man, and my admiration for his outstanding brain, his memory, his enthusiasm and drive grew with our association. With the second collection of Dana deep-sea anglerfishes, we elaborated together Regan's earlier discovery of the parasitic males. Parr's announcement that some males were dwarfed but free-swimming came when we were already working on this collection, and was not a surprise, and the Dana material made it possible for us to relate the free males to their extremely dissimilar mates. This work gave Regan special pleasure, as also did his earlier discovery of the nature and structure of the complicated copulatory organ of the minute East Indian fishes of the family Phallostethidæ. The latter work appeared in 1916, the year before his election to the Royal Society at the age of thirty-nine. 